\title{
Plant-derived smoke and temperature effects on seed germination of five Helianthemum (Cistaceae)
}

\author{
María Martínez-Baniela1 ${ }^{1}$, Luis Carlón', Tomás E. Díaz ${ }^{1}$, Álvaro Bueno ${ }^{1}$ Eduardo Fernández-Pascual ${ }^{1,2 *}$ \\ 1 Jardín Botánico Atlántico, Universidad de Oviedo; Avda. del Jardín Botánico 2230, 33203 Gijón/Xixón, Spain; ${ }^{2}$ \\ Comparative Plant and Fungal Biology, Royal Botanic Gardens, Kew; Wellcome Trust Millennium Building, Wakehurst \\ Place, Ardingly, West Sussex RH17 6TN, UK
}

Corresponding author: Eduardo Fernández-Pascual; Telephone: +44 (0)1444894184; Fax: +44 (0)1444 894110; email: e.fernandezpascual@kew.org

This is a pre-copyedited, author-produced PDF of an article accepted for publication in Aquatic Botany following peer review. The version of record (Martínez-Baniela, M., Carlón, L., Díaz, T. E., Bueno, Á., \& Fernández-Pascual, E. (2016). Plant-derived smoke and temperature effects on seed germination of five Helianthemum (Cistaceae). Flora-Morphology, Distribution, Functional Ecology of Plants, 223, 56-61.) is available online at: http://dx.doi.org/10.1016/j.flora.2016.04.014

\begin{abstract}
Plant-derived smoke promotes germination in Mediterranean-like environments, but its effect is unclear in the Mediterranean Cistaceae. This article investigates the role of smoke in the comparative germination ecology of five Helianthemum taxa. Laboratory germination experiments were conducted using seeds collected in the field and stored in a seed bank. All seeds were mechanically scarified prior to testing. Various pre-treatments with smoke solutions and gibberellins were applied, and seeds were incubated in three germination temperature regimes $\left(30 / 20{ }^{\circ} \mathrm{C}, 22 / 12{ }^{\circ} \mathrm{C}, 14 / 4\right.$ $\left.{ }^{\circ} \mathrm{C}\right)$. In H. cantabricum, H. nummularium, H. oelandicum and $\mathrm{H}$. urrielense germination was very high at the three temperatures, and no effect of smoke was detected. In H. tinetense germination was generally poor and a significant effect of smoke was found, but the effect size was small. The thermal niche of Helianthemum appears to follow an opportunistic strategy, being limited only by physical dormancy at the time of dispersal. H. tinetense follows a more conservative strategy, with physiological dormancy retarding germination. In the Mediterranean basin and surrounding areas, smoke appears to be one of a multitude of environmental signals controlling germination. The smoke effect might be more relevant in certain species such as $\mathrm{H}$. tinetense.
\end{abstract}

Keywords: Atlantic; endemic; fire ecology; Mediterranean; physical dormancy; physiological dormancy

Nomenclature: Castroviejo et al. (1986-2015) Flora iberica

\section{Introduction}

In ecosystems subjected to frequent fire disturbances, heat and smoke are major signals for seed germination (Cushwa et al., 1968; Jefferson et al., 2014). Heat may break the seed coat of physically dormant seeds (Baskin and Baskin, 2014), allowing imbibition during the next rainfall (Herranz et al., 1998). Smoke, produced by burning vegetation, has an important role by itself (van Staden et al., 2000). It carries chemicals, e.g. karrikins (Flematti et al., 2004; Guo et al., 2013), which can overcome physiological dormancy (Baskin and Baskin, 2014). Germination promotion by smoke is common in Mediterranean-like climates where fire plays a central role, like the South African fynbos (Brown, 1993), the Californian chaparral (Keeley and Fotheringham, 1998) and Western Australia (Dixon et al., 1995). Although earlier studies failed to detect a smoke response in the Mediterranean basin (Keeley and Babr-Keeley, 1999; Reyes and Casal, 2006; Reyes and Trabaud, 2009; Rivas et al., 2006), recent work suggests that smoke also promotes germination in the flora of the Mediterranean and surrounding areas (Crosti et al., 2006; Keeley et al., 2011; Mojzes et al., 2015; Moreira et al., 2010; Paula et al., 2009; Pérez-Fernández and Rodríguez-Echeverría, 2003).
Cistaceae are largely linked to the Mediterranean environment (Watson and Dallwitz, 1992). Physical dormancy is a common feature of the family (Ferrandis et al., 1999; Thanos et al., 1992); and post-fire seedling emergence has often been reported (Baskin and Baskin, 2014). A response to smoke has only been found in some species of genera such as Cistus and Fumana (Chen, 2014; Jefferson et al., 2014). In the diverse Helianthemum Mill. genus, heat breaks physical dormancy (Pérez-García and González-Benito, 2006), but attempts to find a germination response to smoke have been unsuccessful so far (Moreira et al., 2010). Five Helianthemum taxa occur in the Cantabrian Mountains (Carlón, 1998; López González, 1993). Seeds of these Cantabrian Helianthemum germinate massively after coat scarification, with the notable exception of the endemic $\mathrm{H}$. tinetense, whose germination percentages are generally low. The special ecology of H. tinetense, closely linked to frequently burnt slopes (Carlón, 1998), makes it a good candidate to find a response to smoke (Mojzes et al., 2015). If such response exists in $\mathrm{H}$. tinetense, it could be interpreted as one of the traits that allowed it to colonize its highly disturbed niche.

Thus, characterizing the germination response to smoke in these closely related Helianthemum can help to clarify the role of this signal in the functional ecology of the 
Mediterranean Cistaceae. For this reason, we conducted a comparative seed germination study with five taxa of Helianthemum, focusing on $\mathrm{H}$. tinetense. It was our goal to test the hypothesis that, in these taxa, and especially in H. tinetense, smoke promotes seed germination.

\section{Materials and methods}

\subsection{Plant material}

In this work we studied the germination of the five Helianthemum (Cistaceae) which occur in the Cantabrian Mountains: Helianthemum apenninum subsp. cantabricum (M. Laínz) G. López; Helianthemum apenninum subsp. urrielense (M. Laínz) G. López; Helianthemum nummularium (L.) Mill.; Helianthemum oelandicum subsp. incanum (Willk.) G. López; and Helianthemum tinetense Mayor \& Fern. Benito. All taxa occupy dry scrub and grasslands at different altitudes. $\mathrm{H}$. tinetense is the only one exclusive of acidic poor soils, usually in fire-prone slopes and road edges (Carlón, 1998).

We used seeds from two sources. First, to compare the germination of the five taxa, we used seeds that had been banked in the Seed Bank of the Jardín Botánico Atlántico (Xixón, Spain). All seed accessions had been collected in natural populations of the Cantabrian Mountains (Supplementary material 1). They had been preserved by drying to $15 \% \mathrm{RH}$ and freezing at $-13{ }^{\circ} \mathrm{C}$ (ENSCONET, 2009 ) and then stored for different time periods (10 to 1 years depending on the taxon, Supplementary material 1). Twenty-four $h$ before the experiments began, we removed seeds from the storage freezers and allowed them to equilibrate to ambient temperature and humidity.

Second, to analyse germination of fresh seeds of $\mathrm{H}$. tinetense, during August 2014 we collected ripe capsules from three natural populations: (1) Tinéu (43 $17^{\circ} 12^{\prime \prime} \mathrm{N}$, $06^{\circ} 31^{\prime} 22^{\prime \prime} \mathrm{W} ; 500 \mathrm{~m}$ above sea level); (2) Ayande (43 $16^{\prime} 11^{\prime \prime} \mathrm{N}, 06^{\circ} 35^{\prime} 30^{\prime \prime} \mathrm{W}$; $\left.650 \mathrm{~m}\right)$; and (3) Ibias ( $43^{\circ} 02^{\prime}$ $25^{\prime \prime} \mathrm{N}, 06^{\circ} 51^{\prime}$ 59" W; $\left.300 \mathrm{~m}\right)$. In each site, we sampled all individuals bearing mature capsules. Capsules stayed in our laboratory (c. $21{ }^{\circ} \mathrm{C}, 50 \% \mathrm{RH}$ ) for two weeks before the start of germination experiments.

To produce a plant-derived smoke solution, we also collected plant remains from the Tinéu population, belonging to the dominant shrubs at the site: Calluna vulgaris, Cytisus striatus and Erica cinerea. We burnt these remains in controlled conditions, and during 5 minutes we impregnated the smoke produced by the combustion into (1) filter paper held $1 \mathrm{~m}$ above the fire (henceforth paper-smoke) and (2) an aerosol of distilled water passed through the smoke column (henceforth water-smoke).

\subsection{Germination experiments}

\subsubsection{General conditions}

To break the seed coat and remove the well-known physical dormancy of Helianthemum (Pérez-García and González-Benito, 2006; Baskin and Baskin, 2014; Royal
Botanic Gardens Kew, 2016), we scarified all seeds with sandpaper before any further manipulation. Afterwards, we exposed seeds to one of four pre-treatments: (1) paper-smoke, $24 \mathrm{~h}$ immersion in $40 \mathrm{~mL}$ of distilled water with four $6 \mathrm{~cm}$ discs of paper-smoke, prepared as described above; (2) water-smoke, $24 \mathrm{~h}$ immersion in 30 $\mathrm{mL}$ of distilled water mixed with $10 \mathrm{~mL}$ of water-smoke, prepared as described above; (3) GA3, $24 \mathrm{~h}$ immersion in $40 \mathrm{~mL}$ of distilled water with gibberellic acid GA3 (0.5 $\mathrm{g} / \mathrm{L}$ ); and (4) control, $24 \mathrm{~h}$ immersion in $40 \mathrm{~mL}$ of pure distilled water. The purpose of the GA3 application was to confirm whether the low germination in $\mathrm{H}$. tinetense was due to physiological dormancy. Then we sowed seeds in $6 \mathrm{~cm}$ Petri dishes holding $1 \%$ agar, and sealed the dishes with Parafilm to prevent agar from drying. We sowed 4 dishes with 25 seeds each per experimental treatment.

We incubated these dishes at one of three alternating temperature regimes programmed inside growth chambers (GROW-360, Ing Climas, Barcelona): (a) $30 / 20{ }^{\circ} \mathrm{C}$, a situation of soil heating; (b) $22 / 12^{\circ} \mathrm{C}$, typical summer temperatures; and (c) $14 / 4^{\circ} \mathrm{C}$, typical autumn or spring temperatures. Temperature regimes were coupled to a photoperiod of $12 \mathrm{~h}$ of light (c. $20 \mu \mathrm{mol} \mathrm{m}-2 \mathrm{~s}-1$ produced by six fluorescent tubes) followed by $12 \mathrm{~h}$ of darkness. Incubations lasted 28 days, during which we scored germination daily, as radicle emergence. After the incubations, we opened non-germinated seeds with a scalpel and classified them as apparently normal, nonscarified (i.e., hard and not imbibed), empty and contaminated by fungi. We removed non-scarified, empty and infected seeds from further calculations. Thus, we considered that the number of potentially germinable seeds in each dish was the sum of germinated and nongerminated but apparently normal seeds. The cumulative number of germinated seeds in each scoring day, and the potentially germinable seeds in each dish, are provided in Supplementary material 2.

2.2.2. Comparative effect of temperature and smoke in Helianthemum

To compare the effect of temperature in the five taxa, and to test if the low germination of $\mathrm{H}$. tinetense was due to a non-optimal germination temperature being used, we incubated non-treated (control) seeds at $30 / 20{ }^{\circ} \mathrm{C}, 22 / 12$ ${ }^{\circ} \mathrm{C}$ and $14 / 4{ }^{\circ} \mathrm{C}$. We sowed both non-stratified (sown directly) and cold-stratified seeds (previous 12 weeks at $3{ }^{\circ} \mathrm{C}$ in darkness and $1 \%$ agar), in order to assess the potential break of physiological dormancy by overwintering. However, in the end the effect of cold stratification could not be considered, because all taxa germinated during stratification (i.e. at $3{ }^{\circ} \mathrm{C}$ in darkness), with similar percentages to those of non-stratified seeds. In addition, to compare the germination response to smoke in the five taxa, we sowed seeds pre-treated with water-smoke at $22 / 12^{\circ} \mathrm{C}$.

\subsubsection{Effect of temperature and smoke in $H$. tinetense}

For $\mathrm{H}$. tinetense, we performed a factorial experiment to analyse the effect of smoke and temperature on the 
germination of fresh seeds from the three natural populations. In this experiment we incubated control, paper-smoke, water-smoke and GA3 treated seeds at $30 / 20{ }^{\circ} \mathrm{C}, 22 / 12{ }^{\circ} \mathrm{C}$ and $14 / 4{ }^{\circ} \mathrm{C}$.

\subsection{Statistical analyses}

We calculated statistics using R (R Development Core Team, 2008). We analysed the effect of the different experimental treatments on the final germination percentage (germinated / potentially germinable) after 28 days of incubation. For this we used Generalised Linear Models (GLM) with binomial error distribution and logit link function. In some treatments that had zero variance because all seeds germinated during the experiment, we subtracted one germinated seed from the fourth Petri dish. We began by fitting three fully factorial models to analyse (a) the effect of taxon and temperature in the genus; (b) the effect of taxon and smoke in the genus; and (c) the effect of population, temperature and smoke in $\mathrm{H}$. tinetense fresh seeds. Afterwards, we performed a stepwise deletion of non-significant terms to produce a minimal adequate model for each case (Crawley, 2013). Then we assessed the significance of different experimental treatments by performing contrasts against a priori selected control treatments (i.e., the $22 / 12{ }^{\circ} \mathrm{C}$ germination temperature, the control smoke treatment, $\mathrm{H}$. tinetense for the genus-level models, and the $\mathrm{H}$. tinetense population with intermediate germination as assessed by visual inspection of the results for the $\mathrm{H}$. tinetense models). For those contrasts that were significant, we calculated the estimated mean and the 95 $\%$ confidence intervals (CI) using the package 'effects' (Fox, 2003). CI are henceforth reported within brackets. Finally, to further visualize differences in the germination processes, we drew the germination progress curves of each treatment by selecting and fitting an appropriate growth function to the cumulative germination data, using the 'drc' package (Ritz and Streibig, 2005).

\section{Results}

\subsection{Comparative effect of temperature and smoke in Helianthemum}

A minimal adequate model for the effect of temperature in the final germination percentages of banked seeds of the five taxa included only the main effects of taxon and temperature (Table 1). Banked $\mathrm{H}$. tinetense seeds had very low germination across temperature, $10.7 \%$ [7.5 15.0]. $H$. cantabricum, $H$. nummularium and $H$. urrielense formed a group with significantly higher germination across temperatures, 96.2\% [94.7 - 97.3]. Finally, H. oelandicum was significantly different from the other Helianthemum, with $100 \%$ germination at the three temperatures. The contrasts for temperature indicated that germination was equally high at $14 / 4{ }^{\circ} \mathrm{C}$ and $22 / 12{ }^{\circ} \mathrm{C}(94.0 \%$ [91.4 - 95.9]), with a significant decrease at $30 / 20{ }^{\circ} \mathrm{C}(86.2 \%$ [80.3 - 90.6]). The comparison of the germination progress curves (Figure 1) highlighted the very fast and complete germination in $\mathrm{H}$. oelandicum at all temperatures, as well as the poorer results in $\mathrm{H}$. tinetense. For the other three taxa, germination at $30 / 20{ }^{\circ} \mathrm{C}$ was remarkably slow compared to the other temperatures, even if the final germination was similar.

Regarding the effect of smoke on the seed germination of the five taxa at $22 / 12{ }^{\circ} \mathrm{C}$, the minimal adequate model included the effects of taxon and smoke and their interaction (Table 1). This was mainly due to the significant interaction in $\mathrm{H}$. nummularium, where germination decreased from $98.9 \%$ [93.1 - 99.9] in the control to $84.5 \%$ [75.1 - 90.7] in the smoke treatment. In $\mathrm{H}$. cantabricum, $\mathrm{H}$. nummularium, $\mathrm{H}$. oelandicum and $\mathrm{H}$. urrielense smoke did not affect the high germination percentages $(98.5 \%$ [97.0, 99.2]). In H. tinetense, smoketreated seeds had a higher average germination $(20.0 \%$ [12.7 - 30.1]) than the control (10.3\% [5.4 - 18.7]); but this difference was not significant (LR $\chi 2=3.076, \mathrm{p}=$ 0.079). The comparison of the germination progress curves (Figure 1) suggests that in $\mathrm{H}$. cantabricum and especially in $\mathrm{H}$. urrielense, smoke produced a slight acceleration of germination. Germination of smoketreated seeds of $\mathrm{H}$. tinetense at $22 / 12{ }^{\circ} \mathrm{C}$ was faster and higher than the germination of control seeds at any of the three temperatures (Figure 1).

\subsection{Effect of temperature and smoke in H. tinetense}

The minimal adequate model for the final germination percentages of fresh $\mathrm{H}$. tinetense seeds included the effects of population, germination temperature and smoke, as well as the interaction between temperature and population (Table 1). The effect of germination temperature depended on the population, as $14 / 4{ }^{\circ} \mathrm{C}$ produced the highest germination percentages in seeds from Tinéu and Ayande, but significantly decreased germination in seeds from Ibias (Figure 2). The contrasts for the population effect indicated significantly more germination across treatments in seeds from Tinéu (83.5\% [82.1 - 85.6]) than in a group formed by Ayande and Ibias $(56.8 \%$ [54.3 - 59.2]). It must be noted that these fresh seeds germinated more than the banked seeds of $\mathrm{H}$. tinetense $(10.7 \%$ [7.5 - 15.0]), which had been collected the previous year from a different population, and whose fresh germination had been even lower $(1 \%$, Supplementary material 1$)$. The contrasts for the smoke treatments created two groups, with significantly lower germination in the control and water-smoke with respect to paper-smoke and GA3, but the effect sizes were small $(64.2 \%$ [61.4 - 66.9] vs. $70.0 \%$ [67.3 - 72.6.5]).

The comparison of the germination progress curves (Figure 2) indicates that germination tended to be faster at $22 / 12{ }^{\circ} \mathrm{C}$ than at either lower or higher temperatures, with steeper slopes at the beginning of the process. The germination progress curves also highlighted the inconsistency of the smoke effect on germination. The control tended to lag behind the other treatments especially at $30 / 20{ }^{\circ} \mathrm{C}$ and in the Ibias population. However, the opposite was also true in some cases such as Ayande seeds at $22 / 12{ }^{\circ} \mathrm{C}$; and in several combinations 
of population and temperature the germination progress in the control matched that in the smoke treatments.

\section{Discussion}

This study shows that Helianthemum germination is defined by a wide thermal niche and a high speed, and also suggests a limited physiological response to smoke. To our knowledge, this is the first report of germination response to smoke in the genus, although it had been found in other Cistaceae (Chen, 2014; Jefferson et al., 2014). Traditionally, it was considered that the flora of the Mediterranean basin differs from other Mediterranean-like floras in that heat only - and not smoke - drives the germination response to fire (Buhk and Hensen, 2006; Keeley and Babr-Keeley, 1999). This view has been challenged in recent studies (Keeley et al., 2011; Paula et al., 2009). In the Mediterranean flora, smoke seems to have a role in promoting the germination of species that do not fully respond to physical dormancy break (Moreira et al., 2010). This could be the case in $\mathrm{H}$. tinetense, but the effect size is so small that it must be interpreted with caution.

We have determined that the optimum temperature for germination in the Cantabrian Helianthemum is around $10-15^{\circ} \mathrm{C}$, which is consistent with previous studies (Escudero et al., 1997; Pérez-García and GonzálezBenito, 2006; Pérez-García et al., 1995). However, the range of germination temperatures is remarkably wide, with similar results between $3{ }^{\circ} \mathrm{C}$ and $30 / 20{ }^{\circ} \mathrm{C}$. The ability to germinate at $3{ }^{\circ} \mathrm{C}$ in darkness suggests that seeds would germinate even under the cover of snow. As field temperatures at the collection sites are almost always within these values, seeds would germinate quickly as soon as the coat breaks and allows water imbibition. Moreover, in addition to a wide germination temperature range, our results show that seeds germinate very fast once physical dormancy has been broken. This phenomenon is generally associated with highly stressful habitats (Gutterman, 2002; Parsons, 2012), where seeds must seize an ephemeral establishment environment. Therefore, the germination of Helianthemum appears to be limited only by the availability of water in the soil and the permeability of the seed coat. The permeability of the seed coat can be regulated either by summer heat cycles or by fire-associated heat (Moreira and Pausas, 2012). Species in which physical dormancy can be broken by summer heat cycles are less bound to fire and can germinate during inter-fire gaps ('facultative pyrogenic dormancy'; Ooi et al., 2014). On the other hand, species in which physical dormancy is only broken by firerelated heat are tightly associated to post-fire germination ('obligate pyrogenic dormancy'; Ooi et al., 2014). As we did not investigate the thermal thresholds for physical dormancy break in our species, we cannot determine whether they fall in the facultative or obligate category.

Nevertheless, in species with pyrogenic dormancy, nongermination of a fraction of the seed population even after heat-related coat break is interpreted as bet-hedging
(Ooi et al., 2014). This seems to be the case of $\mathrm{H}$. tinetense, which was the only studied taxon with consistently low germination percentages in the different tested populations. Of the five studied taxa, the ecology of $\mathrm{H}$. tinetense, linked to disturbed and often burnt slopes (Carlón, 1998), made it a good candidate to respond to smoke (Mojzes et al., 2015). While it is true that the size of this effect was relatively small, it is clear that $\mathrm{H}$. tinetense separates from the general germination pattern of the genus. In this regard, it must be noted that germination increased in response to GA3. The role of gibberellins as promoters of germination through suppression of physiological dormancy is well known (Bewley et al., 2013). Therefore, we can conclude that low germination in $\mathrm{H}$. tinetense is due to a component of physiological dormancy, which joins physical dormancy, and seems to be partially overcome by smoke. Further studies would be needed to investigate the role of smoke in breaking this physiological dormancy. In our experiments, the paper-smoke solution produced a larger effect than water-smoke. This suggests that the concentration of plant-derived smoke compounds could vary between the two solutions, and different concentrations could elicit different germination responses. Therefore, it would be necessary to study the germination of $\mathrm{H}$. tinetense in a more comprehensive range of smoke compounds and concentrations. It would also be worthy to explore further the apparent germination decrease as a response to smoke in $\mathrm{H}$. nummularium, to determine if it is a physiological response or an artefact of the experiments.

In addition, future experiments must clarify the puzzling differences we found between populations. Germination was relatively high in the Tinéu seeds, compared to Ayande and Ibias, and especially low in the seeds obtained from the seed bank and that belonged to a fourth population from Cangas. The low germination of the banked seeds cannot be due to the conservation process, as the initial germination just after collection was even lower (Supplementary material 1). As these seeds were collected in a different site and year, the differences in germination could be due to local adaptation or phenotypic variation in physiological seed dormancy (Fernández-Pascual and Jiménez-Alfaro, 2014; Fernández-Pascual et al., 2013). In any case, it is interesting to note that the size of the smoke effect seemed to be larger in those populations that germinated less (Cangas and Ibias), supporting its potential role as a dormancy-breaking signal.

This study has provided some evidence for a physiological role of smoke in the germination of certain Helianthemum species. The effect appears to be subtle and is masked by the fast germination of the genus. Therefore, it is unclear whether this small effect does have an effect in the regeneration ecology of Helianthemum in the field. Given the reduced response we found, further field experiments are needed to test the relevance of smoke in ecologically-relevant situations. However, the physiological response we describe further 
supports the role of smoke in controlling seed germination in the Cistaceae. Instead of a single major controller of seed germination, it seems to be one of a number of environmental signals (Crosti et al., 2006; Moreira et al., 2010).

\section{Acknowledgements}

We would like to thank J.A. Prieto Domínguez for his participation in seed collection; N. Martínez Vázquez for her help with germination experiments; and the reviewers for improving the manuscript with their comments. E.F.P. was supported by the Government of Asturias and the FP7 Marie Curie COFUND programme of the European Commission (Grant 'Clarín' ACA1419). The Royal Botanic Gardens, Kew receives grant-inaid from Defra. The funder had no part in the design or conduction of the experiments, and neither in the writing and submission of the manuscript.

\section{Acknowledgements}

We wish to thank E. Avilés, I. Bustamante, S. Cockhead, I. Felpete, T. García, V. García, J. Garmendia, T. Gil, J. Ichter, E. Lázaro, P. Penedo, A. Pérez, P. Pevida and M. Saiz for their participation in field expeditions; and V. García, N. Martínez, S. Alegre and A. Piñán for their help with germination experiments. The advice of anonymous reviewers improved the original manuscript. E.F.P. was supported by the Government of Asturias and the FP7 Marie Curie - COFUND programme of the European Commission (Grant 'Clarín' ACA14-19); B.J.A. by the project 'Employment of Best Young Scientists for International Cooperation Empowerment' (CZ.1.07/2.3.00/30.0037) co-financed by the European Social Fund and the state budget of the Czech Republic. The Royal Botanic Gardens, Kew, receive grant-in-aid from Defra..

\section{References}

Baskin, C.C., Baskin, J.M., 2014. Seeds. Ecology, Biogeography and Evolution of Dormancy and Germination. Second Edition. Academic Press, San Diego.

Bewley, J.D., Bradford, K., Hilhorst, H., Nonogaki, H., 2013. Seeds: Physiology of Development, Germination and Dormancy. 3rd Edition. Springer, Berlin - Heidelberg - New York

Brown, N., 1993. Promotion of germination of fynbos seeds by plantderived smoke. New Phytol. 123, 575-583.

Buhk, C., Hensen, I., 2006. "Fire seeders" during early post-fire succession and their quantitative importance in south-eastern Spain. J. Arid Environ. 66, 193-209.

Carlón, L., 1998. Distribución geográfica y comportamiento ecológico de Helianthemum tinetense Mayor López \& Fernández Benito, endemismo astur-galaico. Boletín de Ciencias de la Naturaleza del RIDEA 45, 1-12.

Chen, Y., 2014. The Effect of Smoke on Seed Germination: Global Patterns and Regional Prospects for the Southern High Plains. Texas Tech University.

Crawley, M.J., 2013. The R Book. Second Edition. Chapter 9: Statistical modelling. John Wiley \& Sons, New York - Chichester. pp. 388-448.

Crosti, R., Ladd, P., Dixon, K., Piotto, B., 2006. Post-fire germination: the effect of smoke on seeds of selected species from the central Mediterranean basin. For. Ecol. Manage. 221, 306-312.

Cushwa, C.T., Martin, R.E., Miller, R.L., 1968. The effects of fire on seed germination. J. Range Manage. 21, 250-254.
Dixon, K.W., Roche, S., Pate, J.S., 1995. The promotive effect of smoke derived from burnt native vegetation on seed germination of Western Australian plants. Oecologia 101, 185-192.

ENSCONET, 2009. ENSCONET Curation Protocols \& Recommendations. Royal Botanic Gardens, Kew.

Escudero, A., Carnes, L.F., Pérez-García, F., 1997. Seed germination of gypsophytes and gypsovags in semi-arid central Spain. J. Arid Environ. 36, 487-497.

Fernández-Pascual, E., Jiménez-Alfaro, B., 2014. Phenotypic plasticity in seed germination correlates differentially with overwintering and flowering temperatures. Seed Sci. Res. 24, 273-280.

Fernández-Pascual, E., Jiménez-Alfaro, B., Caujapé-Castells, J., JaénMolina, R., Díaz, T.E., 2013. A local dormancy cline is related to the seed maturation environment, population genetic composition and climate. Ann. Bot. 112, 937-945.

Ferrandis, P., Herranz, J.M., Martínez-Sánchez, J.J., 1999. Effect of fire on hard-coated Cistaceae seed banks and its influence on techniques for quantifying seed banks. Plant Ecol. 144, 103-114.

Flematti, G.R., Ghisalberti, E.L., Dixon, K.W., Trengove, R.D., 2004. A compound from smoke that promotes seed germination. Science $305,977-977$

Fox, J., 2003. Effect displays in R for Generalised Linear Models. J. Stat. Softw. 8, 1-27.

Guo, Y., Zheng, Z., La Clair, J.J., Chory, J., Noel, J.P., 2013. Smokederived karrikin perception by the $\alpha / \beta$-hydrolase KAI2 from Arabidopsis. Proc. Natl. Acad. Sci. USA 110, 8284-8289.

Gutterman, Y., 2002. Survival Strategies of Annual Desert Plants. Springer, Berlin - Heidelberg - New York.

Herranz, J.M., Ferrandis, P., Martínez-Sánchez, J.J., 1998. Influence of heat on seed germination of seven Mediterranean Leguminosae species. Plant Ecol. 136, 95-103.

Jefferson, L., Pennacchio, M., Havens-Young, K., 2014. Ecology of Plant-derived Smoke: Its Use in Seed Germination. Oxford University Press, Oxford.

Keeley, J.E., Babr-Keeley, M., 1999. Role of charred wood, heatshock, and light in germination of postfire phrygana species from the eastern Mediterranean basin. Isr. J. Plant Sci. 47, 11-16.

Keeley, J.E., Fotheringham, C., 1998. Smoke-induced seed germination in California chaparral. Ecology 79, 2320-2336.

Keeley, J.E., Bond, W.J., Bradstock, R.A., Pausas, J.G., Rundel, P.W. 2011. Fire in Mediterranean Ecosystems: Ecology, Evolution and Management. Cambridge University Press, Cambridge.

López González, G., 1993. Helianthemum Mill. In: Castroviejo, S., Aedo, C., Cirujano, S., Laínz, M., Montserrat, P., Morales, R., Muñoz Garmendia, F., Navarro, C., Paiva, J., Soriano, C. (Eds.), Flora iberica 3. Real Jardín Botánico, CSIC, Madrid, pp. 365-421.

Mojzes, B., Csontos, P., Kalapos, T., 2015. Is the positive response of seed germination to plant-derived smoke associated with plant traits? Acta Oecol. 65-66, 24-31.

Moreira, B., Pausas, J.G., 2012. Tanned or burned: the role of fire in shaping physical seed dormancy. PLoS One 7, e51523.

Moreira, B., Tormo, J., Estrelles, E., Pausas, J., 2010. Disentangling the role of heat and smoke as germination cues in Mediterranean basin flora. Ann. Bot. 105, 627-635.

Ooi, M.K.J., Denham, A.J., Santana, V.M., Auld, T.D., 2014 Temperature thresholds of physically dormant seeds and plant functional response to fire: variation among species and relative impact of climate change. Ecol. Evol. 4, 656-671.

Parsons, R., 2012. Incidence and ecology of very fast germination. Seed Sci. Res. 22, 161-167.

Paula, S., Arianoutsou, M., Kazanis, D., Tavsanoglu, Ç., Lloret, F., Buhk, C., Ojeda, F., Luna, B., Moreno, J., Rodrigo, A., 2009. Firerelated traits for plant species of the Mediterranean Basin: Ecological Archives E090-094. Ecology 90, 1420-1420.

Pérez-Fernández, M.A., Rodríguez-Echeverría, S., 2003. Effect of smoke, charred wood, and nitrogenous compounds on seed germination of ten species from woodland in central-western Spain. J. Chem. Ecol. 29, 237-251.

Pérez-García, F., González-Benito, M., 2006. Seed germination of five Helianthemum species: effect of temperature and presowing treatments. J. Arid Environ. 65, 688-693.

Pérez-García, F., Iriondo, J.M., González-Benito, M.E., Carnes, L.F., Tapia, J., Prieto, C., Plaza, R., Pérez, C., 1995. Germination studies in endemic plant species of the Iberian Peninsula. Isr. J. Plant Sci. 43, 239-247. 
R Development Core Team, 2008. R: A language and environment for statistical computing, 3.0.2 ed. R Foundation for Statistical Computing, Vienna, Austria.

Reyes, O., Casal, M., 2006. Seed germination of Quercus robur, Q pyrenaica and Q. ilex and the effects of smoke, heat, ash and charcoal. Ann. For. Sci. 63, 205-212.

Reyes, O., Trabaud, L., 2009. Germination behaviour of 14 Mediterranean species in relation to fire factors: smoke and heat. Plant Ecol. 202, 113-121.

Ritz, C., Streibig, J.C., 2005. Bioassay analysis using R. J. Stat. Software 12, 1-22.

Rivas, M., Reyes, O., Casal, M., 2006. Influence of heat and smoke treatments on the germination of six leguminous shrubby species. Int. J. Wildland Fire 15, 73-80.

Royal Botanic Gardens Kew. 2016. Seed Information Database (SIS). Version 7.1. Available from: http://data.kew.org/sid/ (accessed March 2016).

van Staden, J., Brown, N.A., Jäger, A.K., Johnson, T.A., 2000. Smoke as a germination cue. Plant Species Biol. 15, 167-178.

Thanos, C.A., Georghiou, K., Kadis, C., Pantazi, C., 1992. Cistaceae: a plant family with hard seeds. Israel J. Bot. 41, 251-263.

Watson, L., Dallwitz, M., 1992. The families of flowering plants: descriptions, illustrations, identification, and information retrieval. Version: 4th March 2011. biodiversity. uno. edu/delta 
Table 1 Minimal adequate models fitted to the results of the germination experiments: comparative effect of temperature in the genus, comparative effect of smoke in the genus, and effect of temperature and smoke in fresh Helianthemum tinetense seeds.

\begin{tabular}{|c|c|c|c|c|c|}
\hline Model & Parameter & Estimate & S.E. & $\mathrm{Z}$ & $\mathrm{p}$ \\
\hline Comparative & Intercept $\left(H\right.$. tinetense at $\left.14 / 4+22 / 12^{\circ} \mathrm{C}\right)$ & -1.813 & 0.199 & -9.104 & $<0.001$ \\
\hline \multirow[t]{3}{*}{ temperature } & Taxon $(H$. cantabricum $+H$. nummularium $+H$. urrielense $)$ & 5.359 & 0.275 & 19.490 & $<0.001$ \\
\hline & Taxon $($ H. oelandicum $)$ & 6.788 & 0.620 & 10.948 & $<0.001$ \\
\hline & Temperature $\left(30 / 20^{\circ} \mathrm{C}\right)$ & -0.926 & 0.275 & -3.364 & $<0.001$ \\
\hline Comparative & Intercept (H. tinetense, control) & -2.160 & 0.352 & -6.134 & $<0.001$ \\
\hline \multirow[t]{5}{*}{ smoke } & Taxon $(H$. cantabricum $+H$. oelandicum $+H$. urrielense $)$ & 6.724 & 0.679 & 9.906 & $<0.001$ \\
\hline & Taxon (H. nummularium) & 6.7450 & 1.065 & 6.333 & $<0.001$ \\
\hline & Smoke (Water-smoke) & 0.773 & 0.450 & 1.720 & 0.085 \\
\hline & Taxon $(H$. can. + H. oel. + H. urr. $) *$ Smoke (Water-smoke) & -1.550 & 0.842 & -1.840 & 0.064 \\
\hline & Taxon $(H$. num. $) *$ Smoke (Water-smoke) & -3.660 & 1.142 & -3.206 & 0.001 \\
\hline H. tinetense & Intercept (Ayande at $22 / 12^{\circ} \mathrm{C}$ with control or water-smoke) & 0.170 & 0.120 & 1.426 & 0.154 \\
\hline \multirow[t]{9}{*}{ fresh seeds } & Smoke (Paper-smoke $\left.+\mathrm{GA}_{3}\right)$ & 0.264 & 0.088 & 3.012 & 0.003 \\
\hline & Temperature $\left(14 / 4^{\circ} \mathrm{C}\right)$ & 0.330 & 0.163 & 2.027 & 0.043 \\
\hline & Temperature $\left(30 / 20^{\circ} \mathrm{C}\right)$ & -0.106 & 0.164 & -0.656 & 0.512 \\
\hline & Population (Ibias) & 0.347 & 0.184 & 1.890 & 0.059 \\
\hline & Population (Tinéu) & 1.394 & 0.182 & 7.681 & $<0.001$ \\
\hline & Population (Ibias) $*$ Temperature $\left(14 / 4^{\circ} \mathrm{C}\right)$ & -1.227 & 0.256 & -4.786 & $<0.001$ \\
\hline & Population (Ibias) $*$ Temperature $\left(30 / 20{ }^{\circ} \mathrm{C}\right)$ & -0.492 & 0.260 & -1.893 & 0.058 \\
\hline & Population (Tinéu) $*$ Temperature $\left(14 / 4{ }^{\circ} \mathrm{C}\right)$ & -0.342 & 0.260 & -1.317 & 0.188 \\
\hline & Population (Tinéu) $*$ Temperature $\left(30 / 20^{\circ} \mathrm{C}\right)$ & -0.113 & 0.260 & -0.434 & 0.665 \\
\hline
\end{tabular}




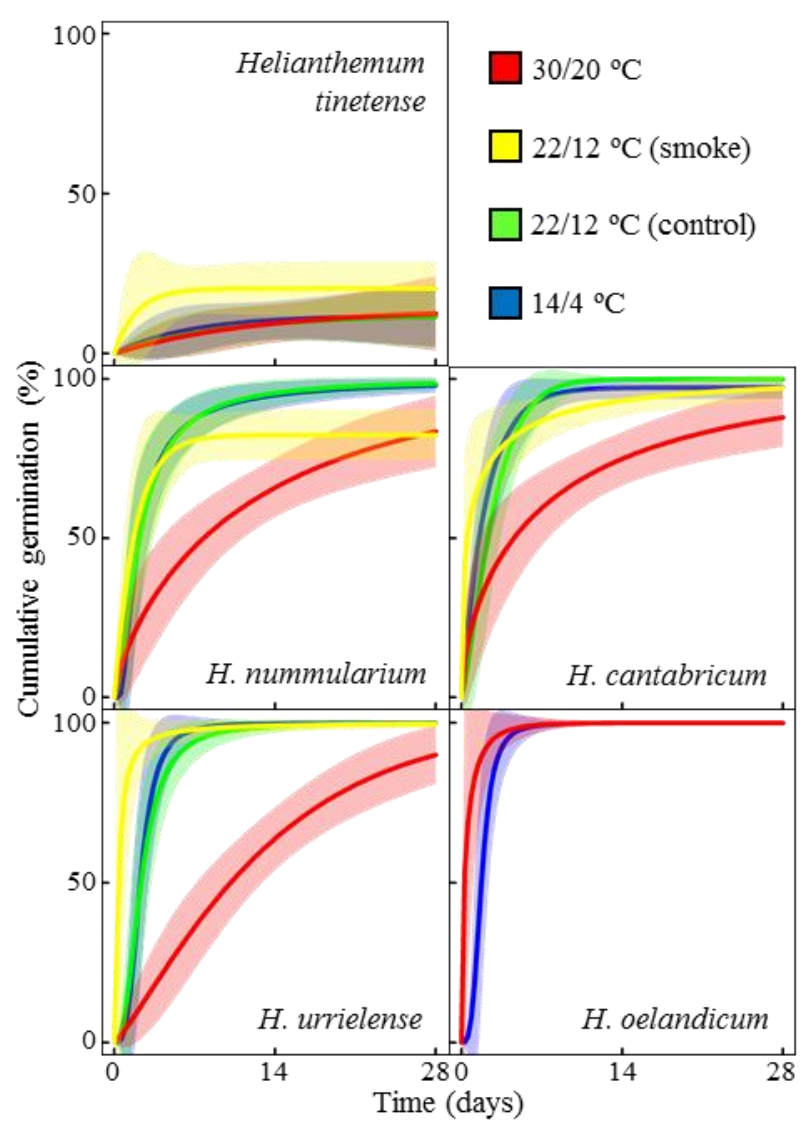

Figure 1 Germination progress of banked seeds from five Helianthemum taxa. Seeds were germinated at three temperature regimes, and seeds at $22 / 12{ }^{\circ} \mathrm{C}$ were also pre-treated with plant-derived smoke (water-smoke). Darker curves are growth functions fitted to data using the package 'drc'. In each treatment, a best fit function was selected between the log-logistic, asymptotic regression and Weibull. Lighter areas are the $95 \%$ confidence interval of each curve. Colour online only. 


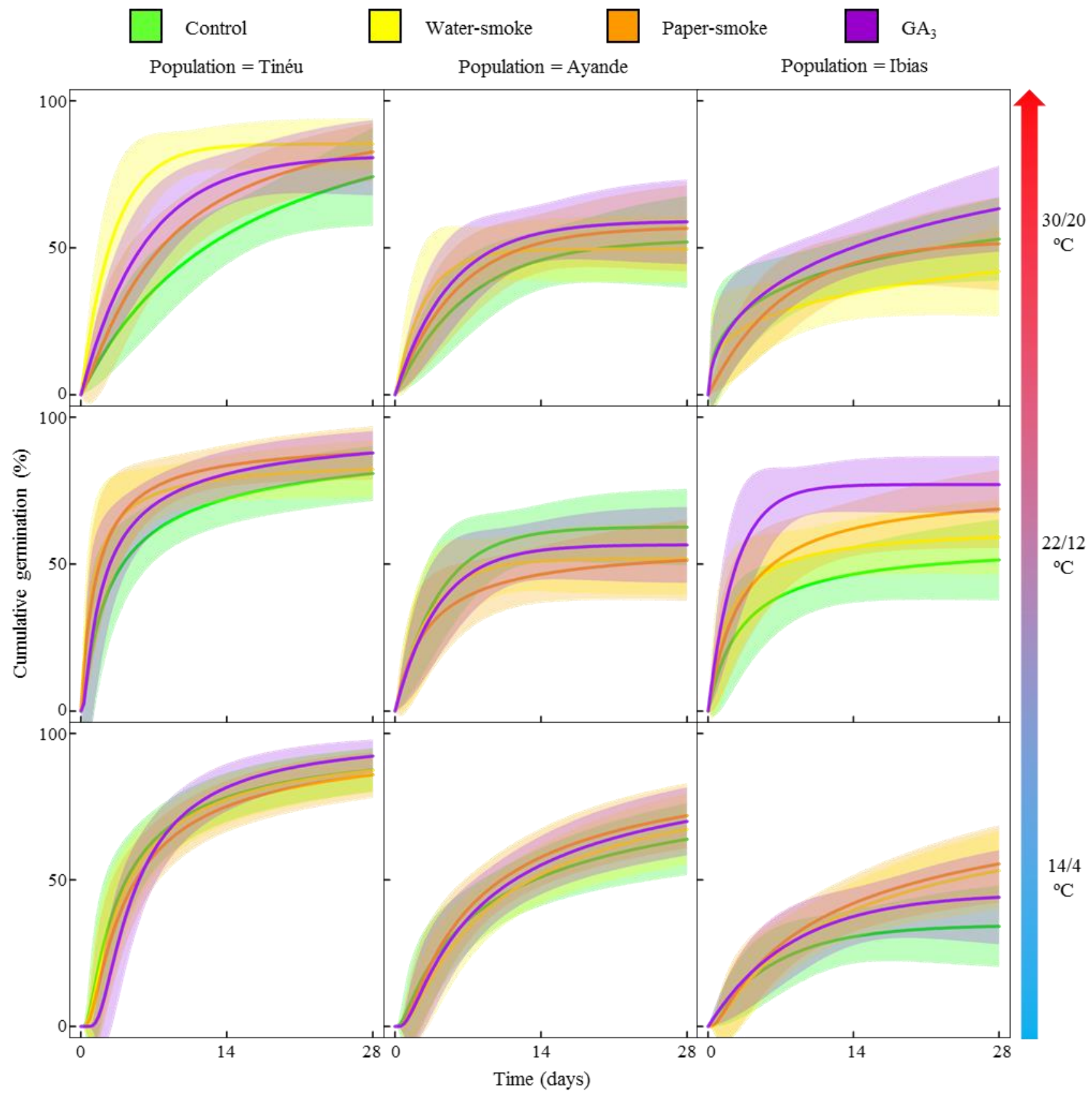

Figure 2 Germination progress of fresh Helianthemum tinetense seeds collected in three populations. Seeds were germinated at three temperature regimes, and pre-treated with distilled water (control), plant-derived smoke (water-smoke and paper-smoke) or GA3. Darker curves are growth functions fitted to data using the package 'drc'. In each treatment, a best fit function was selected between the log-logistic, asymptotic regression, Weibull and Michaelis-Menten. Lighter areas are the $95 \%$ confidence interval of each curve. Colour online only. 